\title{
Institutional Dimension Levering Factor on Halal Tourism Sustainability in Banyuwangi
}

\author{
Muksin* \\ Agribusiness Departement \\ Politeknik Negeri Jember \\ Jember, Indonesia \\ muksin@polije.ac.id
}

\author{
D N Mutmainah \\ Agribusiness Departement \\ Politeknik Negeri Jember \\ Jember, Indonesia
}

\author{
Sri Sundari \\ Agribusiness Departement \\ Politeknik Negeri Jember \\ Jember, Indonesia
}

\author{
D Purwoko \\ Center for Society and Culture \\ Research \\ Indonesian Institute of Sciences \\ Jakarta, Indonesia
}

\author{
Bustang \\ Directorate of State Apparatus \\ National Development Planning \\ Agency \\ Jakarta, Indonesia
}

\begin{abstract}
Tourism of Banyuwangi santen island is the only marine tourism that is categorized halal tourism in East Java. The local government's efforts to develop halal tourism. The increase in tourist visits has led to some conflict of management between community groups. There are several factors from the institutional dimension of society that have influence and have not been used in the direction of halal tourism development in Banyuwangi. Inadequate management will affect the sustainability and growth of halal tourism. This research aims to assess the status of sustainability and leverage factors in the institutional dimension of halal tourism development. The research method uses expert assessments to identify and evaluate 14 attributes or elements, and the analysis is carried out using Multi-Dimensional Scaling (MDS) to assess the sustainability status of institutional dimensions in halal tourism development. The results of the study of the institutional dimension show that halal tourism is categorized as entirely sustainable. Factors or attributes that are very sensitive that to be driven on the sustainability of the institutional dimension on the development of halal tourism is the access of tour conscious groups to the source of technology, transparency in policy, and availability of community organizations.
\end{abstract}

Keywords--institutional, leverage factor, halal tourism, and sustainability

\section{INTRODUCTION}

The tourism sector is a sector that has a significant influence on economic growth and social welfare. Tourism affects the well-being of people [1]. Indonesia's tourism sector, especially the Banyuwangi district, which is developing is marine tourism. Coastal tourism, from various other coastal tourism activities, significantly impacts economic growth in countries that have coastlines, which are utilized by many countries to increase value-added as income [2]. The development of marine tourism has two interests at the same time, namely the parts of community economic development and management of coastal marine ecosystems to be sustainable.

The demand or need for tourism is increasing. This need has become a global phenomenon. The global phenomenon is shown by the increasing number of tourists from various countries visiting a tourism object. One of the tourism objects that tend to increase in visits is tourism objects with the concept of halal tourism. Halal tourism is a tourism that provides a dimension of facilitating the implementation of one's religious religiosity apart from tourist attraction. The idea of halal tourism is associated with a nuanced or offering of religiosity or tourism that provides hospitality or adaptability to the Muslim community [3]. The sense of halal tourism is also to distinguish tourist travel that only aims to have fun without benefiting from the fun, and is closer to hedonistic activities [4].

Halal tourism is increasingly getting appreciation from visitors from various countries. One of these appreciations is shown by Indonesia winning the top position in the Mastercard-Crescent Rating index "Global Muslim Travel Index" (GMTI) 2019. This appreciation offers the highest assessment from the international community on the management and growth of halal tourism in Indonesia.

Although Indonesia received this appreciation, the growth of halal tourism in Indonesia is still concentrated in several provinces, namely Aceh and West Nusa Tenggara. Three provinces on the island of Java have only one halal tourism in East Java. The halal tourism is Santen Island which is located in Banyuwangi, East Java. The concept of halal tourism on the island of Santen is beach tourism that seeks to apply halal principles to meet the needs of specific visitor segments.

Halal tourism on the island of Santen has only been around for four years. At the beginning of its establishment, this tour received an enthusiastic welcome from both domestic and foreign tourists. However, since the last two years, this tourist attraction has experienced a decline in visits. The decrease in visits had an impact on the economic activities of the surrounding community. Also, the reduction in visits makes it difficult for managers to manage tourism facilities and infrastructure that require operational costs. Poorly managed facilities and infrastructure will decrease the quality of the facilities, which will affect the attractiveness and convenience of visitors. 
Based on information from the community, there is a management conflict between several interested parties. The stakeholders referred to include the surrounding community, district government and the military, in this case, the Indonesian National Army. Some of these parties have different views on the management of Santen Island. Apart from several conflicts between these parties, there is a condition that the role and involvement of institutions in the direction of these halal tourism objects are not optimal.

The ongoing conflict and lack of optimism will have an impact on the sustainability of halal tourism on the island of Santen. The level of management optimality will also affect the overall attractiveness of Santen Island. The story of attraction has an impact on the dynamics of tourist visits. Based on the consideration of these conditions, it is essential to analyze the state of the sustainability status of halal tourism in Santen Island, leverage factors in the institutional dimension which can then be used as the formulation of models and scenarios for the development of sustainable halal tourism on Santen Island in Banyuwangi.

\section{METHODS}

The template is used to format your paper and style the text. All margins, column widths, line spaces, and text fonts are prescribed; please do not alter them. You may note peculiarities. For example, the head margin in this template measures proportionately more than is customary. This measurement and others are deliberate, using specifications that anticipate your paper as one part of the entire proceedings, and not as an independent document. Please do not revise any of the current designations.

This study uses a qualitative approach and focuses on making decisions based on the judgment of the experts. The determination of the research location was carried out deliberately, namely on the island's halal tourism, with the address of the Karangrejo Village, Karanganom Environment, Banyuwangi Kota District, Banyuwangi Regency. The assessment and judgment involved experts, namely the managers of Santen Island, the Banyuwangi Regency Tourism Office, groups of tourism awareness activists, ecotourism researchers, and academics who have competence in the field of halal tourism.

Analysis of data originating from experts using the Multidimensional scaling (MDS) method. The MDS method will help formulate the position of a related factor to determine the linkages and influences between elements from the specified institutional dimensions. The determination of the factors is based on a literature review. Based on the expert's assessment, the formulation of the sustainability status of the halal tourism of Santen Island will be obtained which is described on a continuum, namely the right points (good) and bad points (bad).

Furthermore, Ordination Analysis using the MDS method, namely the position of the point of sustainability can be visualized through the horizontal axis and the vertical axis. With the rotation process, the point position can be visualized on the horizontal axis with the sustainability index value given a score of $0 \%$ (bad) and $100 \%$ (right). If the system under study has a sustainability index value greater than or equal to $50 \%$ (>50\%), then the system is said to be sustainable, and it is said to be unsustainable if the index value is less than $50 \%$
$(<50 \%)$. The cost of the sustainability index uses a scale developed by the University of Columbia, Canada, as presented in Table 1 below:

TABLE 1. CATEgory of Sustainability Status

\begin{tabular}{cc}
\hline Index Value & Category \\
\hline $0.00-25.00$ & Bad (unsustainable) \\
$25.01-50.00$ & Less (less sustainable) \\
$50.01-75.00$ & $50.01-75.00$ Fair (quite sustainable) \\
$75.01-100,00$ & $75.01-100,00$ Good (very sustainable) \\
\hline
\end{tabular}

\section{RESULT AND DISCUSSIONS}

Analysis of the sustainability of tourism in Banyuwangi Regency was carried out to determine the status of the sustainability of halal tourism, especially in the halal tourism of Santen Island, Sharia Beach, which is in Karangrejo Village, Banyuwangi Regency. This sustainability analysis can be seen from the institutional dimension as a dimension that affects the sustainability of the halal tourism of Santen Island. Factors or attributes of the institutional dimension are the capacity of capital for tourism awareness groups, tourism awareness group institutions, financial institutions, tourism marketing agencies, access to tourism awareness groups to technology sources, synchronization of central policies, availability of social institutions, availability of community organizations, availability of supervision and law enforcement. , Extension of legal management of natural resources and the environment, transparency in the policy of participation of religious institutions, extension centres, and cooperation with other regions.

The sustainability of halal tourism in Banyuwangi Regency seen from the institutional dimension can be seen in Figure 1 below:

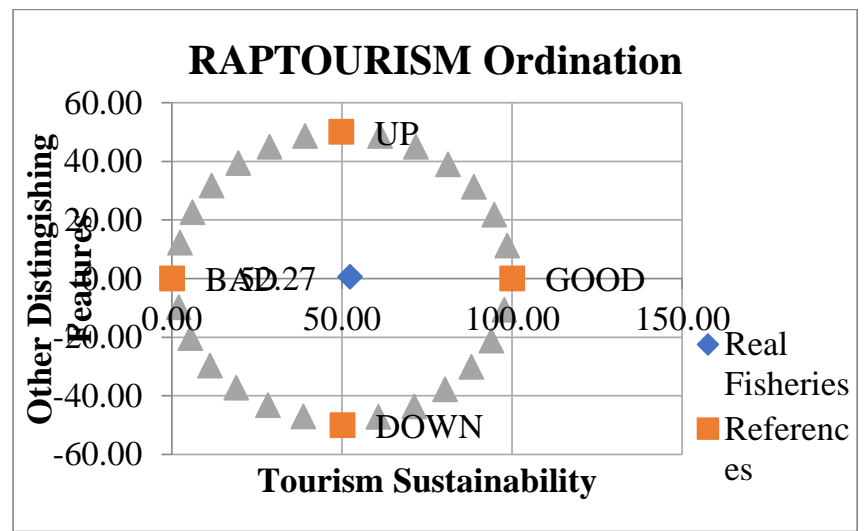

Fig. 1. Status of Sustainability Based on Institutional Dimensions.

Based on the institutional dimension based on Figure 2, halal tourism in Banyuwangi Regency is categorized as Sufficiently Sustainable with a value of 52.27. The influence of each attribute on the institutional dimension on the sustainability of halal tourism in Banyuwangi Regency can be seen in Figure 2.

Based on Figure 2, it can be seen that the leveraging factors that affect the institutional dimension and need to be considered are the Access to Tourism Awareness Groups to Technology Resources with an attribute effect value of 2.43 and Transparency in Policy with an attribute effect value of 1.95 . 


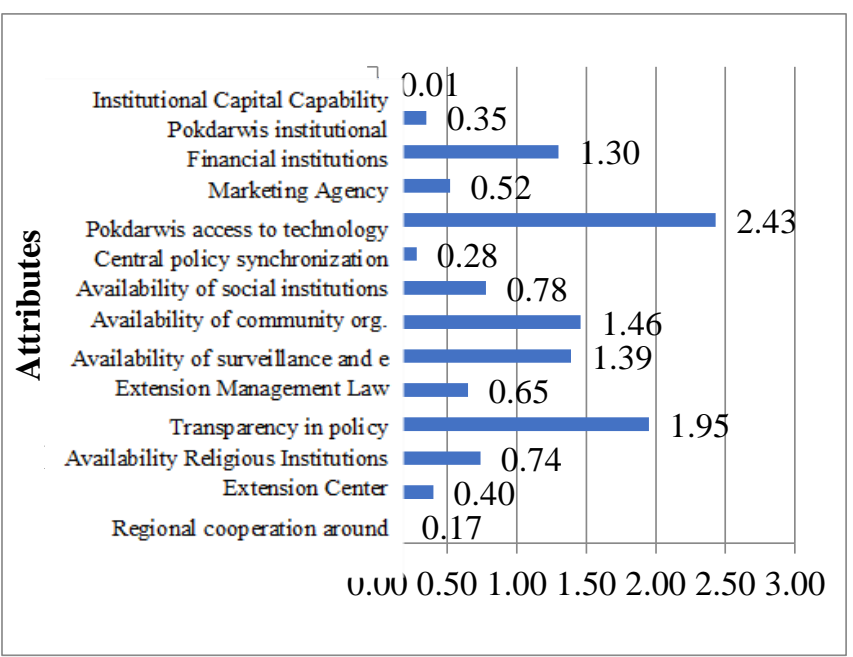

Fig. 2. The Effect of Attributes on the Institutional Dimension.

Halal tourism on the island of Santen Pantai Syariah is located in the middle of Banyuwangi City, which is indeed not far from the technology centre. Halal tourist locations are close to several agencies in Banyuwangi Regency, especially the Culture and Tourism Office of Banyuwangi Regency. If this situation is utilized optimally by the manager of halal tourism, there will be no decrease in visitors to the halal tourism of Santen Island, Sharia Coast. Halal tourism managers are deemed to be lacking in communication, both in the form of cooperation between managers and the village and office or in the way of developing halal tourism. There is more than one social program that has been provided by the Social Service for the sustainability of halal tourism; one of the programs is making chairs with waste-based materials. Garbage along the coast is collected for cleaning activities on Monday and Friday at 06.00 WIB until finished. This wastebased chair making program is beneficial for managers in terms of cleanliness and beauty of halal tourism. However, institutional management has not been optimally able to continue the program sustainably.

Some government assistance and efforts have also been made for the sustainability of halal tourism. The Regional Government has also provided funds for the construction of Extension Centers in halal tourism. The Banyuwangi Regency Culture and Tourism Office has also offered several assistance in the form of beach chairs and umbrellas, fan chairs, empowerment and training for local communities, and much more. The manager has underutilized this opportunity, this is what causes halal tourism to experience a setback in terms of tourism development in Banyuwangi.

Another leveraging factor is Transparency in Policy. This means that there is nothing that needs to be covered in the sustainable development of halal tourism in Banyuwangi Regency, between land managers and owners (TNI-AD), managers with the Regional Government, managers with the Culture and Tourism Office, and other policies under supervision. And law enforcement in halal tourism. Transparency is the openness of all actions and approaches taken by the government. Government transparency can also be defined as the ability to explain what is happening in an organization in the public sector through open meetings, namely in terms of providing access to general information documents through websites actively, protecting website blowers, and through illegal leakage of information. Transparency provides recognition that the role of the government is quite significant in facilitating the condition and development of regional tourism. The government's role is also to provide facility on the participation drive [5]. In principle, transparency is part of the government's efforts to foster public trust in the government, as well as involving the community in carrying out the controlling function of all efforts made by the government to improve community welfare, especially for local communities in halal tourism in Banyuwangi Regency. That way there will be no misunderstanding between some of the parties concerned, regarding the development of halal tourism on the Sharia Coast of Santen Island.

\section{CONCLUSION}

The halal tourism object of Santen Island is categorized as entirely sustainable, which means that this tourism object requires serious efforts from the institutional dimension so that it can be maintained and provide benefits to the surrounding community. Attributes related to governance to increase the participation of tourism-conscious groups in access to technology, transparency in policies, and the existence of organizations are urgent matters that need to be prioritized to be addressed. These attributes in the institutional dimension will affect the dynamics of other characteristics in the development of halal tourism.

\section{ACKNOWLEDGMENT}

We express our gratitude to some parties. The excellent cooperation and attention of the Banyuwangi Regency Tourism Office, the Army Forces, and the people of Santen Island and its surroundings have maximally assisted the completion of this research. We hope that this research finding will inform strategic decision-making in the development of halal tourism that provides welfare benefits to society and the ecology at large.

\section{REFERENCES}

[1] I. Mafruhah, S. Supriyono, N. S. Mulyani, and N. Istiqomah, "Causality between tourism industry development and the ecological sustainability in marine environment: A convergence and divergence among stakeholder with mactor analysis," Int. J. Energy Econ. Policy, vol. 10, no. 4, pp. 85-92, 2020, doi: 10.32479/ijeep.7989.

[2] D. Jang, W. Cho, and K. Lee, "A Study on the development strategy for marine leisure tourism: Using the Importance Performance Analysis (IPA) method," Sport Mont, vol. 18, no. 1, pp. 39-45, 2020, doi: 10.26773/smj.200207.

[3] Erianjoni, Ganefri, O. Oktorie, and A. Kristian, "the Effect of Halal Tourism Destination Program on Sociocultural Characteristics Toward Education Development," vol. 1, no. 1, pp. 17-27, 2018, [Online]. Available: http://senjop.ppj.unp.ac.id/index.php/senjop/article/view/7.

[4] Z. Samori, N. Z. Md Salleh, and M. M. Khalid, "Current trends on Halal tourism: Cases on selected Asian countries," Tour. Manag. Perspect., vol. 19, no. February, pp. 131-136, 2016, doi: 10.1016/j.tmp.2015.12.011.

[5] G.B Saputra, Muksin, dan Merry Muspita. "AGROTOURISM DEVELOPMENT IN LEDOKOMBO DISTRICT, JEMBER REGENCY", Jurnal Ekonomi Pertanian dan Agribisnis. Vol. 2, no 4, pp 325-331, 2018, doi: 10.21776/ub.jepa.2018.002.04.7 